\title{
LYON NATURAL RADIOCARBON MEASUREMENTS IV
}

\author{
J. EVIN, G. MARIEN, and Ch. PACHIAUDI
}

Radiocarbon Laboratory, Geology Department, University of Lyon I, Nuclear Physics Institute, 69, Villeurbanne, France

\section{INTRODUCTION}

This list includes most of the samples measured from June 1970 to June 1972 and some other results not yet published in previous date lists.

Chemical treatment of samples and counting technique remain as described previously (R., 1969, v. 11, p. 112-113; R., 1973, v. 15, p. 134-155). See also Longin (1971) for bone preparations performed by solubilization of collagen in acid hot water.

Ages are calculated using the half-life value 5570 with 1950 as reference year. The statistical errors, corresponding to one standard deviation, include contemporary standard, background, and sample counts.

\section{ACKNOWLEDGMENTS}

We thank Yvette Chiarlone for chemical preparations and most routine operations. We are grateful to J. Flandrin and P. Elouard, Dept. of Geology, for their continuous support, and to A. Sarazin and the staff of the Nuclear Physics Institute for their help and technical assistance.

\section{SAMPLE DESCRIPTIONS}

I. GEOLOGIC SAMPLES

\section{Ly-583. Roudil, Tarn}

$4220 \pm 130$

2270 B.C.

Clayey peat from 47 to $55 \mathrm{~cm}$ depth in Roudil peat bog, near Arfous, Tarn (43 $26^{\prime} \mathrm{N}$ Lat, $2^{\circ} 31^{\prime}$ E Long.) Coll. and subm. 1971 by J. L. de Beaulieu, Lab. Bot. Hist., Univ. Provence, Marseille. Level marks beginning of Fagus increase in pollen diagram. Comment (J. L. de B.): low alt. of site might suggest a Sub-Atlantic age for Fagus increase, as in Malaroumet peat bog, Dordogne: Lv-387: $1570 \pm 80$ в.P. (R., 1970, v. 12, p. 554). But here it seems closer to Fagus increase in Les Estables peat bog, Pyrénées Orientales, a little later than Gif-1199: $5120 \pm 130$ B.P. (R., 1972, v. 14, p. 308) and in Les Laubies peat bog Lv-515: $3590 \pm 140$ B.P. (R., 1971, v. 13, p. 358); see also Lacaune D 70, 105 (Ly-545, below).

\section{Lacaunes series, Tarn}

Peat from several levels in a peat bog, alt. $1022 \mathrm{~m}$ in Monts de

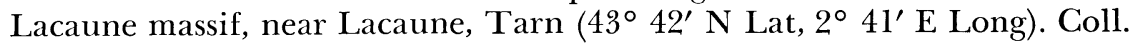
and subm. 1970 by J. L. de Beaulieu.

$$
1750 \pm 110
$$

Ly-543. Lacaune D 70, $50 \mathrm{~cm}$

$50 \mathrm{~cm}$ below surface, pollen diagram marks Fagus and Abies decline under human influence. 
Ly-544. Lacaune D 70, $85 \mathrm{~cm}$

$85 \mathrm{~cm}$ below surface, pollen diagram marks Fagus and Abies maximum and Ulmus decline.

\section{Ly-545. Lacaune D 70, $105 \mathrm{~cm}$}

$5480 \pm 140$

3530 в.c.

$105 \mathrm{~cm}$ below surface, bottom of boring; pollen diagram marks Quercus and Corylus maximum, attributed to end of Atlantic A.

General Comment (J. L. de B.): age as expected. Fagus increase at $-95 \mathrm{~cm}$ may be extrapolated to end of Atlantic B, ca. 4000 B.P., which also agrees with dates of peat bogs of neighboring mts. (e.g., Ly-583, this list) (de Beaulieu and Evin, 1972).

\section{Eyzin-Pinet series, Isère}

Wood from La Gère R. alluvium near Eyzin-Pinet, Isère $\left(45^{\circ} 29^{\prime} \mathrm{N}\right.$ Lat, $5^{\circ} 00^{\prime}$ E Long.) Coll. and subm. 1971 by G. Chapotat, Centre de recherches et Etudes archéol. de Vienne, Isère.

\section{Ly-536. Eyzin-Pinet, Ey $n^{\circ} 1$}

$2040 \pm 150$

Fragment of a large tree trunk.

Ly-537. Eyzin-Pinet, Ey $n^{\circ} 2$

90 в.c.

Fragment of a wooden picket, assoc. with Celtic pottery.

General Comment (G. C.): Ly-537 agrees with expected age. Ly-536 proves tree is contemporaneous with industry and does not belong to ancient alluvium (Chapotat and Samuel, 1972).

\section{Ly-509. Les Angles, Corrèze}

$2600 \pm 380$

650 B.c.

Wood coll. by boring in a sandy layer, $35 \mathrm{~m}$ deep and $8 \mathrm{~m}$ below Corrèze R. bed at Les Angles, Corrèze (45 $18^{\prime} \mathrm{N}$ Lat, $1^{\circ} 38^{\prime} \mathrm{E}$ Long.) Coll. et subm. 1971 by J. P. Meunier, Elec. de France, Paris. Boring was in right bank of river, at a dam site planned by Entente Interdept. Corrèze-Dordogne for Dir. Dept. l'Equipement de la Dordogne. Comment (J.P.M.): sandy layer underlies $35 \mathrm{~m}$ fissured gneiss. Date suggests gneiss slid over a sand bank in ancient channel of Corrèze $\mathbf{R}$.

Ly-504. Moirans, Isère

$4640 \pm 140$

Wood coll. by boring $7 \mathrm{~m}$ deep, in alluvium in former channel of Isère R. (45 $17^{\prime}$ N Lat, $5^{\circ} 36^{\prime} \mathrm{E}$ Long). Coll. and subm. 1971 by MAPAFIT Soc. Grenoble. Comment: shows thickness of recent filling in Isère R. low valley.

Ly-556. Frache, Monétier-Allemont, Hautes-Alpes

Modern

Fragment of tree trunk uprooted in alluvium of Frache torrent $\left(44^{\circ}\right.$ $23^{\prime} \mathrm{N}$ Lat, $5^{\circ} 57^{\prime}$ E Long). Coll. and subm. by M. Archambault, Dept. 
Lettres et Sci. Humaines, Univ. Orléans. Alluvium is related to $40 \mathrm{~m}$ terrace of Durance R. Comment: tree does not belong to old sediments.

\section{Ly-557. Les Eymarrons, Ribiers, Hautes-Alpes}

$530 \pm 200$

Fragment of tree trunk uprooted in erosion slope, middle terrace of Le Buech R. at Les Eymarrons near Ribiers, Hautes-Alpes (44 $13^{\prime} \mathrm{N}$ Lat, $5^{\circ} 43^{\prime}$ E Long). Coll. and subm. 1970 by M. Archambault. Comment (M.A.): proves tree is modern and does not belong to colluvium material of terrace, despite its fossilized aspect.

\section{Ly-558. Messires Odou, Sigottier, Hautes-Alpes}

$8620 \pm 380$ 6670 B.c.

Fragment of tree trunk rooted and fossilized in colluvial slime, under surface of slope of low terrace of Le Buech R. near Sigottier, Hautes-Alpes ( $44^{\circ} 28^{\prime}$ N Lat, $5^{\circ} 44^{\prime}$ E Long). Coll. and subm. 1970 by M. Archambault. Comment (M.A.): as expected, date is postglacial for the terrace. See also Ly-555 (below).

\section{Ly-555. Les Barbiers, Lazer, Hautes-Alpes}

$9250 \pm 190$

7300 B.c.

Fragment of tree trunk rooted in clay on Les Barbiers torrent bank, near Lazer, Hautes-Alpes ( $44^{\circ} 21^{\prime} \mathrm{N}$ Lat, $5^{\circ} 50^{\prime} \mathrm{E}$ Long). Coll. and subm. 1970 by M. Archambault. Comment (M.A.): as expected, date is postglacial for sediments and assoc. Le Buëch R. low terrace. Cf. Ly-227: $11,250 \pm 250$ B.P. (R., 1971, v. 13, p. 53) from Cuculiane site, in the same valley, $6 \mathrm{~km}$ away, and $\mathrm{Ly}-558$ (this list).

Ly-546. Les Guinguettes, Vaux-Milieu, Isère

Modern

Bovine bones from $1 \mathrm{~m}$ depth in sandy fluvial gravel of Würmian moraine at Les Guinguettes near Vaux-Milieu, Isère $\left(45^{\circ} 37^{\prime} \mathrm{N}\right.$ Lat, $5^{\circ} 11^{\prime}$ E Long). Coll. and subm. 1971 by B. Walter, Géol. Dept., Univ. Lyon. Comment (B.W.): old age was expected, considering deposit conditions, but date indicates bones were buried in sediments.

\section{Ly-547. Trou Bernier, Géovreisset, Ain}

A.D. 1580

$370 \pm 100$

Ox and horse bones from Le Trou Bernier near Géovreisset, Ain $\left(46^{\circ} 15^{\prime} \mathrm{N}\right.$ Lat, 5 ${ }^{\circ} 37^{\prime} \mathrm{E}$ Long). Coll. 1971 by P. Bernier and subm. 1971 by C. Guérin, Géol. Dept., Univ. Lyon. Comment (C.G.): bones are recent, although they underlie thick forest soil.

\section{Ly-362. Rivière souterraine de La Balme d'Epy, Jura

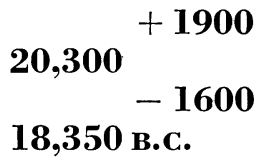

Underground river of La Balme d'Epy, Jura. Bones of large mammal from bed of an underground river $800 \mathrm{~m}$ inside a grotto near La Balme d'Epy, Jura (46 23' N Lat, 5 $5^{\circ} 25^{\prime} \mathrm{E}$ Long). Coll. in 1970 by C. Guérin. Comment (C.G.): perfect agreement with attributed late-Würm fauna 
(Crocuta spelaea, Mammuthus primigenius, Coelodonta antiquitatis, Equus caballus, and Bison priscus) and shows that collagen partly remains in bones, despite long immersion.

\section{Grotte des Hyènes series, Le Blanc, Indre}

Bones of large mammal from Les Hyènes Grotto near Le Blanc, Indre ( $47^{\circ} 22^{\prime} \mathrm{N}$ Lat, $1^{\circ} 42^{\prime} \mathrm{E}$ Long). Coll. and subm. 1971 by C. Guérin.

\section{Ly-548. Grotte des Hyènes, salle des Hyènes}

Ly-549. Grotte des Hyènes, entonnoir

General Comment (C.G.): dates exclude attribution to Würm III or Würm IV; these bones cannot be contemporaneous with neighboring Magdalenian site, Saint-Marcel and Abri Fritch, Indre.

\section{Ly-441. Châtillon Saint-Jean, Drôme}

Bones of large mammal from $10 \mathrm{~m}$ depth in Fournier Quarry at Châtillon Saint-Jean, Drôme (45 $5^{\circ} 5^{\prime} \mathrm{N}$ Lat, $5^{\circ} 08^{\prime} \mathrm{E}$ Long). Coll. 1961 and subm. 1971 by C. Mourer-Chauviré, Géol. Dept., Univ. Lyon. The quarry is in alluvium of $70 \mathrm{~m}$ terrace Isère R. Comment (C.M.): assoc. pollen indicates cold-steppe phase. Because of high position of terrace had been attributed to Mindel, but species suggest a Würm age also (Chauviré and Weiss, 1962). But date proves that it cannot be Würm IV or III cold phases.

\section{Ly-511. Grotte de l'Aldène, Cesseras, Hérault}

$6860 \pm 190$

Calcium carbonate from upper part of stalagmitic floor obstructing one entrance of l'Aldène Grotto, near Cesseras, Hérault (43 $18^{\prime} \mathrm{N}$ Lat, $2^{\circ} 48^{\prime}$ E Long). Coll. and subm. 1971 by H. de Lumley, Lab. paleontol. humaine et Préhist., Univ. Marseille. Comment (H. de L.): grotto contains Magdalenian paintings. Despite lack of information of this material, date shows, as expected, that entrance, presently obstructed, was open at time of paintings.

\section{KS 05 and KS 06 marine core series, Mediterranean Sea}

$>100 \mu$ fractions of Globigerina mud from 2 borings in bottom of Mediterranean Sea between Algeria and Balearic Is. Core KS $06\left(38^{\circ} 31^{\prime}\right.$ $\mathrm{N}$ Lat, $4^{\circ} 00^{\prime} \mathrm{E}$ Long), 2293m depth, and Core KS $05\left(38^{\circ} 06^{\prime} \mathrm{N}\right.$ Lat, $2^{\circ} 59^{\prime}$ E Long), $2710 \mathrm{~m}$ depth. Samples coll. 1970 by Centre Océanol. Bretagne and subm. 1972 by L. Leclaire, Lab. Géol., Mus. Natl. d'Hist. Natl., Paris. For all samples, amount of available material was ca. $5 \mathrm{~g}$.

\section{Ly-589. KS $05 n^{\circ} 1$}

From 70 to $105 \mathrm{~cm}$ in KS 05 core.
$9470 \pm 530$

$\mathbf{7 5 2 0}$ B.C.

$\delta \boldsymbol{C}^{13}=+0.41 \%$ o 
Ly-590. KS 05 no 2

From 200 to $250 \mathrm{~cm}$ in KS 05 core.

\section{Ly-591. KS 05 no 3}

From 305 to $340 \mathrm{~cm}$ in KS 05 core.

\section{Ly-592. KS 06 n $^{\circ} 1$}

From 70 to $110 \mathrm{~cm}$ in KS 06 core.

\section{Ly-593. KS $06 n^{\circ} 2$}

From 200 to $245 \mathrm{~cm}$ in KS 06 core.

\section{Ly-594. KS 06 no 3}

From 310 to $340 \mathrm{~cm}$ in KS 06 core. $\geqslant 21,100$

${ }_{\delta} C^{13}=-29.70 \%$

$13,320 \pm 1070$

\section{1,370 B.c.}

$\delta C^{13}=+1.45 \%$

$$
\geqslant \mathbf{2 5 , 0 0 0}
$$

$\delta C^{13}=-1.68 \%$ 。

$\geqslant 30,000$

$\delta C^{13}=-1.63 \%$

General Comment (L.L.): confirms expected range of dates deduced from paleoclimatic curve established by Foraminifera and $0^{18}$ studies. At the same depth, sediments formed just before postglacial time are older in KS 06 than in KS 05. This may indicate either a different sedimentation rate or a stratigraphic gap in the KS 06 sequence. $\delta \mathrm{C}^{13}$ values are in normal range of marine sediments except the very negative value Ly-591, which remains unexplained (Leclaire, 1972).

\section{ARCHAEOLOGIC SAMPLES}

\section{A. Bourgogne, Franche-Comte, Lorraine}

\section{Ly-579. Thoraise, Doubs}

$2400 \pm 130$ 450 B.C.

Wood from hearth of a kiln at Thoraise, Doubs $\left(45^{\circ} 10^{\prime} \mathrm{N} \mathrm{Lat,} 5^{\circ} 54^{\prime}\right.$ E Long). Coll. and subm. 1970 by P. Pétrequin, Dir. antiquités préhist., Besançon. Comment (P.P.): agrees with La Tène I-IIa industry and older than Gif-1842: $2180 \pm 70$ в.P., from same place.

\section{Ly-580. Florange F2, Moselle}

$2600 \pm 130$ 650 B.C.

Charcoal from hearth of a kiln at Sainte-Agathe, near Florange, Moselle $\left(49^{\circ} 20^{\prime} \mathrm{N}\right.$ Lat, $6^{\circ} 07^{\prime} \mathrm{E}$ Long). Coll. and subm. 1970 by $\mathrm{P}$. Pétrequin. Comment (P.P.): assoc. industry is middle Hallstatt ceramic of low Rhine facies (Pétrequin et al., 1972). Date agrees perfectly and also fits with Gif-1843: $2500 \pm 70$ B.P., from same site.

Ly-578. La Motte aux Magnins $n^{\circ}$ 2, Clairvaux, Jura 2530 B.c.

Wood from Level 1 in coastal sta. La Motte aux Magnins in Le Grand Lac, near Clairvaux, Jura ( $46^{\circ} 34^{\prime} \mathrm{N}$ Lat, $5^{\circ} 45^{\prime} \mathrm{E}$ Long). Coll. and subm. 1970 by P. Pétrequin. Comment (P.P.): date disagrees with Late 
Bronze assoc. industry (bronze awl and glass-paste pearl) but agrees with Middle Neolithic industry of underlying levels. Charcoal probably came from an older sta. and was redeposited during last rise of lake. The same explanation should hold for Ly-384, from the same site, previously described for coastal sta. Les Roseaux islet, Chalain Lake, Jura: Ly-385 (R., 1973, v. 15, p. 143).

Ly-513. Abri Gay, Poncin, Ain

$5490 \pm 110$

Charcoal from Level 6b, W part of Abri Gay rock shelter, near Poncin, Ain ( $46^{\circ} 05^{\prime} \mathrm{N}$ Lat, $5^{\circ} 24^{\prime} \mathrm{E}$ Long). Coll. and subm. 1971 by R. Desbrosse, Blanzy, Saône et Loire. Assoc. to industry attributed to Tardenoisian. Comment (R.D.): Neolithic date is much younger than expected. May indicate Mesolithic industry lasted a long time in region. No ceramics were found in level (Desbrosse, 1971).

\section{Thoys series, Arbignieu, Ain}

Samples from several levels of Thoys rock shelter, near Arbignieu, Ain ( $45^{\circ} 45^{\prime}$ N Lat, 5 39' E Long). Coll. 1969 and 1970 by N. S. Morelon and subm. by R. Vilain, Dept. Géol., Univ. Lyon.

Ly-285. Thoys $\mathrm{n}^{\circ} 1$ and 2

$2100 \pm 160$

Charcoal from level with Chalcolithic industry. Comment (R.V.): as expected, proves upper levels were disturbed.

\section{Ly-269. Thoys no 5}

$6190 \pm 160$

Charcoal assoc. with Sauvetrian industry, Boreal period.

\section{Ly-619. Thoys $\mathrm{n}^{\circ} 8$}

$6850 \pm 420$

4900 B.C.

Charcoal from same level as Ly-269. Comment (R.V.): date confirms Ly-269. Both dates are younger than expected by industry but Mesolithic may have been very prolonged in region.

\section{Ly-270. Thoys $n^{\circ} 6$ and 7}

$9350 \pm 300$

Charcoal from carbonaceous level, assoc. with a transition industry, between Azilian and Sauveterrian types, attributed to Pre-Boreal period. Comment (R.V.): date agrees with both attributions.

Ly-620. Thoys $n^{\circ} 9$

$10,220 \pm 650$

Small amount of charcoal from same layer as Ly-270. Comment (R.V.): date confirms Ly-270. Both dates are in statistical range.

\section{Ly-599. Thoys $\mathrm{n}^{\circ} 11$}

$9390 \pm 150$

Calcium carbonate from same carbonaceous level as Ly-270 and Ly-620. Comment (R.V.): despite lack of knowledge of original $\mathrm{C}^{14}$ value of that type of material, value is same as for Ly-270. 
Ly-567. Grotte de la Balme, Cuiseaux, Saône et Loire

Modern

Bones from entrance of La Balme grotto at La Balme, Cuiseaux, Saône et Loire (46 $30^{\prime} \mathrm{N}$ Lat, 5 ${ }^{\circ} 23^{\prime} \mathrm{E}$ Long). Coll. 1962 by Vuillemey and subm. 1971 by J. Combier, Dir. antiquités préhist., Romanèche Thorins, Saône et Loire. Assoc. with some elements of Magdalenian industry. Comment (J.C.): disturbance confirmed of upper sediments of grotto.

\section{Grotte Grappin series, Arlay, Jura}

Bones from several levels of Grappin grotto at Saint-Vincent, near Arlay, Jura (46 $46^{\prime} \mathrm{N}$ Lat, 5 $31^{\prime}$ E Long). Coll. 1961 by M. Vuillemey and subm. 1971 by J. Combier.

\section{Ly-497. Arlay $\mathrm{n}^{\circ}$ 1, Level g, Sq. J to $\mathrm{N}$}

$15,320 \pm 370$

Bones from several animal species of Late Quaternary. Level underlies a stalagmitic floor in center of grotto at $0.5 \mathrm{~m}$ depth; that part of grotto was destroyed by a quarry. Assoc. Magdalenian industry.

\section{Ly-559. Arlay no 2, Level g, Sq. P to T}

$15,770 \pm 390$

Bones of several animal species from front grotto, $0.4 \mathrm{~m}$ deep. Assoc. Magdalenian industry.

\section{Ly-498. Arlay $n^{\circ}$ 3, Level e}

$25,520 \pm 820$

Bones (Ursus spaeleus) embedded in clayey level, $1.2 \mathrm{~m}$ deep.

\section{Ly-499. Arlay no 4, Level c}

$25,920 \pm 900$

Ursus spaeleus and Hyena spelea embedded in clayey level $2.0 \mathrm{~m}$ deep, overlying a stalagmitic floor.

General Comment (J.C.): Ly-497 and -559 assoc. with particular Magdalenian industry comparable to Central European facies (Combier, 1954) and may be contemporaneous with Middle Magdalenian of region, age Würm IV. Both dates seem a little too old for La Croze II Middle Magdalenian site, expected older: Ly-434: 14,850 3550 B.P. (R., 1973, v. 15, p. 150). Ly-498 and Ly-499 give a Würm III age to lowest levels, as expected by similar sediments in other grottos in Jura (see Ly-362, this list).

\section{Solutré series, Solutré, Saône et Loire}

Bones from several levels of Solutré foot of cliff site, Solutré, Saône et Loire $\left(46^{\circ} 18^{\prime} \mathrm{N}\right.$ Lat, $4^{\circ} 43^{\prime} \mathrm{E}$ Long). Except Ly-647, samples coll. and subm. 1969 by J. Combier. Layers consist of conglomerated horse bones and so-called "Magma de Cheval," mostly Perigordian (Würm III b).

Ly-560. Solutré no 4 bis, Sondage b, Level 6 $\geqslant 30,400$

Small uncharred horse bones. Same level as Ly-312: 28,650 \pm 1100 (R., 1971, v. 13, p. 64). Three-sigma criteria used for age limit calculation. 


\section{Ly-561. Solutré $n^{\circ} 5$ his, Sondage b, Level $6 \quad 21,250 \pm 700$}

Uncharred horse bones. Same level as Ly-313: 22,650 5500 (R., 1971, v. 13, p. 64).

\section{Ly-562. Solutré $n^{\circ} 7$, Sondage Terre sève,} Level 6

$21,600 \pm 700$

Uncharred horse bones.

\section{9,650 в.c.}

\section{Ly-647. Barbare de Solutré}

$$
1550 \pm 90
$$

Human bones coll. 1923 by C. Deperet and L. Mayet and subm. 1972 by J. Combier. From burial in level attributed to Upper Aurignacian, (Riquet, 1955) overlain by layer of unconglomerated horse bones that slid into $\mathrm{W}$ part of site. Comment (J.C.): a new examination of the old excavation (Combier, 1955) attributes burial to High Middle age cemetery, established in the archaeologic layers. Date agrees with that and anthropologic character of skeletons.

General Comment (J.C.): Ly-560 and -561 confirm difference between Ly-312 and -313 and hypothesis of mixing, in level, of older small bones (may be Aurignacian). Ly-561 and -562 agree well with Solutré 11: Ly-317: 24,050 400 and Saint-Martin-sous-Montaigu, Saône et Loire: Ly-309/31 1: 23,550 4400 (R., 1971, v. 13, p. 63), both assoc. with Upper Perigordian industry.

\section{Ly-566. Grotte de La Balme, Gigny-sur-Suran, Jura}

$29,500 \pm 1400$ 27,550 B.c.

Small bones from Level VIII in La Balme grotto, at Gigny-sur-Suran, Jura (46 $27^{\prime} \mathrm{N}$ Lat, $5^{\circ} 27^{\prime} \mathrm{E}$ Long). Coll. 1962 by M. Vuillemey and subm. 1971 by J. Combier. Assoc. with Levallois facies industry ("Laminaire" Late Mousterian, attributed to end of Würm II/III interstadial). Comment (J.C.): consistent with sedimentology and very evolved character of industry; but needs confirmation from other measurements. Date should indicate contemporaneity between Middle Paleolithic industries (Late Mousterian) from E France and Upper Paleolithic industries (Lower Perigordian and Aurignacian) from Dordogne.

\section{B. Dauphiné, Auvergne}

\section{Gué de l'Ozon series, Sérézin-du-Rhône, Rhône}

Samples from the ford of a Roman road on Ozon R., near Sérézin-duRhône (45 $38^{\prime} \mathrm{N}$ Lat, $4^{\circ} 55^{\prime} \mathrm{E}$ Long). Coll. and subm. 1971 by $\mathrm{G}$. Chapotat (1972).

Ly-535. Gué de l'Ozon, Se no 1

$330 \pm 140$

Wood from $1 \mathrm{~m}$ depth, set in lowest layers of road metal. 
Ly-584. Gué de l'Ozon, Se no 2

Ferruginous scoriae from upper layer of surface of road.

Ly-585. Gué de l'Ozon, Se no 3

$18,500 \pm 700$

Ferruginous scoriae from another road overlying the Roman one, probably from the Middle age.

General Comment (G.G.): 3 dates differ from expected values: Ly-535 proves wood was pushed in from actual soil. Ly-584 and -585 show roads were metaled with scoriae partly of coal. There are coal outcrops at Communay, $7 \mathrm{~km}$ from Sérézin.

\section{Grésine 2 series, Savoie}

Samples from Coastal sta. Grésine 2, submerged $4.5 \mathrm{~m}$ in middle of $\mathrm{E}$ bank of Le Bourget lake, near Brison Saint-Innocent, Savoie $\left(45^{\circ} 44^{\prime} \mathrm{N}\right.$ Lat, 5 $5^{\circ} 53^{\prime}$ E Long). Coll. and subm. 1971 by R. Laurent, Centre de Recherches Archéol. Lacustres, Tresserves, Savoie.

\section{Ly-506. Grésine $2 n^{\circ} 1$}

$1280 \pm 120$

Small wooden stake in lacustrian chalk assoc. with pottery debris.

Ly-507. Grésine $2 \mathbf{n}^{\circ} 2$

$1500 \pm 360$

Small wooden stake in lacustrian chalk, close to Ly-506.

\section{Ly-508. Grésine $2 \mathrm{n}^{\circ} 3$}

$2840 \pm 300$

Wood from pile foundation, center of coastal sta.

890 B.C.

General Comment (R.L.): Ly-506 and -507 prove that small stakes are relatively recent fishery posts that carried ancient pottery downward into lacustrian chalk. Ly-508 confirms Late Bronze age of sta., which is contemporaneous with Châtillon sta., N part of lake; see Ly-274: $2670 \pm 110$ (R., 1971, v. 13, p. 57).

\section{Ly-595. Les Sarrasins, Level 5, Isère}

$3850 \pm 120$

Charcoal from Level 5b in Les Sarrasins grotto, near Seyssinet-Pariset,

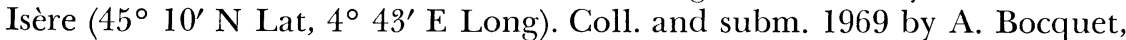
Grenoble. Assoc. with decorated vessel North Alp type. Comment (A.B.): when sample was subm., expected age was at the limit between Middle and Early Bronze ages because of vessel decoration. Comparison with Clairvaux sta., Jura, suggests a full Early Bronze age corresponding to ceramic and metal of Arbon-Bleich sta., Switzerland, confirmed by date. Underlying level (7) was previously dated, Gif-1204: $3900 \pm 120$ (R., 1972, v. 14, p. 287) and is now attributed to Late Chalcolithic, with "Caliciforme" and "cordé" ceramic. Both dates agree perfectly. 


\section{Ly-296. Corent, Puy-de-Dôme}

$4150 \pm 100$

2200 B.c.

Charcoal from Corent oppidum, Puy-de-Dôme $\left(45^{\circ} 40^{\prime} \mathrm{N}\right.$ Lat, $3^{\circ} 11^{\prime}$ E Long). Coll. and subm. 1970 by J. P. Daugas, Dir. Antiquités préhistoriques, Clermont-Ferrand, Puy-de-Dôme. Comment (J.P.D.): date confirms industry is local evolution of Chassean to Chalcolithic influenced by civilizations of SE France (Daugas, 1972).

\section{Ly-336. Le Taï, Saint-Nazaire-en-Royans, Drôme A.D. 460}

$1490 \pm 250$

Charcoal from upper layer La Grotte du Taï site, near Saint-Nazaireen-Royans, Drôme (45 $09^{\prime} \mathrm{N}$ Lat, $5^{\circ} 15^{\prime} \mathrm{E}$ Long). Coll. and subm. 1970 by J. and J. Brochier, Lab. Paléontol., Univ. Marseille. Assoc. with Epipaleolithic industries. Comment (J. and J. B.): proves upper layers were disturbed.

\section{Ly-539. La Baume Loire III, Haute-Loire}

$7100 \pm 180$

Small pieces of charcoal from rock shelter La Baume Loire III, near Solignac, Haute-Loire (44 $56^{\prime} \mathrm{N}$ Lat, $3^{\circ} 54^{\prime} \mathrm{E}$ Long). Coll. and subm. 1971 by A. Crémilleux, Le Monastier-sur-Gazeille, Haute-Loire. Comment (A.C.): agrees well with assoc. industry, Tardenoisian without ceramics (Crémilleux, 1971). Should be compared to level 70 to $80 \mathrm{~cm}$, Longetraye site (this list).

\section{La Grotte Béraud series, Saint-Privat d'Allier, Haute-Loire}

Charcoal from several levels in La Grotte Béraud site, near SaintPrivat d'Allier, Haute-Loire (44 $58^{\prime}$ N Lat, $3^{\circ} 40^{\prime} \mathrm{E}$ Long). Coll. and subm. by A. Quinqueton, Le Puy, Haute-Loire. The 4 lowest levels contain 2 hearth zones, all with same industry that may correspond to Late Magdalenian with Azilian characters.

\section{Ly-49. Grotte Béraud AD 1}

A.D. 1350

$600 \pm 150$

Coll. and subm. 1967, from $70 \mathrm{~cm}$ depth in upper layers. Comment (A.Q.): just above a Middle age sepulchre; agrees well.

\section{Ly-358. Grotte Béraud IN $\mathbf{I N}_{2} 156$}

$7110 \pm 140$

Coll. and subm. 1970, from $95 \mathrm{~cm}$ depth in upper hearth zone.

\section{Ly-197. Grotte Béraud GN 3}

$6640 \pm 800$

Very small amount of charcoal, coll. and subm. 1969, from $110 \mathrm{~cm}$ depth, Level 3, just above lowest hearth zone, in part of site very rich in industry.

\section{Ly-646. Grotte Béraud GN 4}

Coll. and subm. 1972, from $120 \mathrm{~cm}$ depth in lowest hearth zone.

General Comment (A.Q.): Ly-358, -197, and -646 are coherent with stra- 
tigraphy; deposit conditions seem to exclude all contamination. However, dates are much younger than indications of industry, which may be due to alt. or remote position of site, where Epimagdalenian characters may have lasted longer than elsewhere.

\section{Longetraye series, Haute-Loire}

Charcoal from rock shelter Longetraye, near Freycenet-la-Cuche, Haute-Loire (44 $52^{\prime} \mathrm{N}$ Lat, $3^{\circ} 55^{\prime} \mathrm{E}$ Long). Coll. and subm. 1970 and 1971 by D. Philibert, Lab. d'Ethnol., Univ. Lyon. Site is at $1200 \mathrm{~m}$ alt. in a cold region and was probably only a passage shelter for hunters. Dated to guide archaeologic digging and verify correlations of several levels.

\begin{tabular}{|c|c|c|c|c|c|c|c|}
\hline Ly-409. & Longetraye & Sq. & $\mathrm{D}$, & Layer & 1 & 0 to $50 \mathrm{~cm}$ & $\begin{array}{l}4640 \pm 350 \\
2690 \text { в.C. }\end{array}$ \\
\hline Ly-615. & , & $"$ & $6 \mathrm{E}$, & , & 1 & 20 to $30 \mathrm{~cm}$ & $\begin{array}{l}3820 \pm 140 \\
1870 \text { в.С. }\end{array}$ \\
\hline Ly-616. & , & ", & $6 \mathrm{E}$, & " & 2 & 50 to $60 \mathrm{~cm}$ & $\begin{array}{l}6210 \pm 170 \\
4260 \text { B.C. }\end{array}$ \\
\hline Ly-617. & , & " & $6 \mathrm{E}$ & , & 3 & 70 to $80 \mathrm{~cm}$ & $\begin{array}{l}7320 \pm 140 \\
5370 \text { в.С. }\end{array}$ \\
\hline Ly-410. & , & , & $\mathrm{D}$, & , & 2 & 80 to $100 \mathrm{~cm}$ & $\begin{array}{l}8420 \pm 280 \\
6470 \text { B.C. }\end{array}$ \\
\hline Ly-618. & ", & ", & $6 \mathbf{E}$ & ", & 4 & 100 to $120 \mathrm{~cm}$ & $\begin{array}{l}8220 \pm 190 \\
6270 \text { в.С. }\end{array}$ \\
\hline Ly-411. &, & $"$ & $\mathrm{D}$, & $"$ & 3 & 140 to $160 \mathrm{~cm}$ & $\begin{array}{l}8450 \pm 310 \\
6500 \text { B.C. }\end{array}$ \\
\hline Ly-5 12. & , & $"$ & $6 \mathrm{E}$ & , & 4 & 170 to $190 \mathrm{~cm}$ & $\begin{array}{l}12,720 \pm 750 \\
10,770 \text { в.с. }\end{array}$ \\
\hline
\end{tabular}

General Comment (D.P.): Ly-409 and -615 prove that upper layers of site are polluted. Other results show that stratigraphy is regular and levels may be followed horizontally. Ly-512 gives Magdalenian age to lowest layer, agreeing with assoc. industry. Middle layers assoc. with Mesolithic industries and dates all generally agree with dates from low alt. sites.

\section{Le Blot series, Cerzat, Haute-Loire}

Samples from several levels of Le Blot site at Chambon, near Cerzat, Puy-de-Dôme (45 $18^{\prime} \mathrm{N}$ Lat, $3^{\circ} 28^{\prime} \mathrm{E}$ Long). Coll. and subm. by J. P. Daugas.

\section{Ly-563. Le Blot, Level 3}

$14,030 \pm 500$

Charred bones: coll. 1967, subm. 1969. Treated as uncharred bones by collagen extraction. Assoc. industry: Magdalenian.

\section{Ly-502. Le Blot, Level 10 b}

$11,250 \pm 500$

Charcoal coll. 1967; subm. 1969. Assoc. industry: Magdalenian. 
Small amount of charcoal. Coll. 1967; subm. 1969. Assoc. industry Magdalenian.

\section{Ly-564. Le Blot, Level J M}

$21,700 \pm 1200$

19,750 в.c. Proto-Magdalenian.

\section{Ly-565. Le Blot, Level G J}

$21,500 \pm 700$

Carbonaceous earth. Coll. and subm. 1970. Assoc. industry: Early Proto-Magdalenian.

General Comment (J.P.D.): Ly-563 is older than expected but quite possible because industry is rare and not very characteristic. Ly-502 and -501 are incompatible, one is too young, the other, too old: in both levels charcoal may have floated, come from rise deposits of a river, and may have heterogeneous origin. Ly-564 and -565 come from 2 hearths $3 \mathrm{~m}$ away at same depth. Assoc. industry is Proto-Magdalenian with "Micro-pointes" La Gravette. For both hearths, overlying level also has Proto-Magdalenian industry, but without La Gravette point, i.e., of Laugerie Haute and Abri Pataud types (Delporte, 1970). Expected age was a little older than the dates of these sites: Abri Pataud: GrN-4231: 21,380 \pm 340 (R., 1967, v. 9, p. 113-114) and Laugerie Haute: GrN-1876: 21,980 \pm 250 (R., 1963, v. 5, p. 167). Ly-564 and -565 are quite comparable but, considering statistical range, the possibility that Le Blot Early Proto-Magdalenian is slightly older is not excluded.

\section{Languedoc, Provence Occidentale}

\section{Ly-554. Grotte de Boucoiran, Gard}

$4140 \pm 120$

Charcoal from Layer 2a in sepulchral grotto at Boucoiran, Gard ( $44^{\circ} 00^{\prime} \mathrm{N}$ Lat, $4^{\circ} 11^{\prime} \mathrm{E}$ Long). Coll. 1969 by A. Coste and subm. 1970 by J. L. Roudil, Montpellier. Comment (J.L.R.): agrees well with assoc. "Fontbouïsse" Chalcolithic industry (Roudil et al., 1970).

\section{Grotte Bourbon series, Gard}

Samples from Bourbon grotto at Les Planès, near Cabrières, Gard (43 $54^{\prime} \mathrm{N}$ Lat, $4^{\circ} 29^{\prime} \mathrm{E}$ Long). Coll. and subm. 1970 and 1971 by J. L. Roudil, Montpellier.

\section{Ly-412. Grotte Bourbon C2}

Charcoal assoc. with Chassean industry. Comment (J.L.R.): 500 to 700 yr older than expected for Chassean in region; sample may be contaminated. But lithic industry is close to Late Cardial industry of underlying layer: Ly-538 and ceramic have archaïc characters; such an old age is not excluded. 


\section{Ly-633. Grotte Bourbon C3}

3350 B.C.

Bones from same level as Ly-412. Comment (J.L.R.): agrees better with ages generally admitted for Chassean in SE France. May be compared to MC-8: $5220 \pm 230$ from La Madeleine grotto, Hérault (R., 1964, v. 6, p. 195) and to Gif-1485: $5100 \pm 130$ from Camprafaud site, Hérault, Level 13 (R., 1972, v. 14, p. 286).

\section{Ly-538. Grotte Bourbon C5}

Charcoal assoc. with Late Cardial ceramics. Comment (J.L.R.): agrees with other dates of Cardial in region: Ly 303/304: 6220 \pm 100 from La Baume de Montclus, Layer 4 (R., 1971, v. 13, p. 62).

\section{Montclus series, Gard}

Samples from rock shelter La Baume de Montclus, Gard $\left(44^{\circ} 16^{\prime} \mathrm{N}\right.$ Lat, 4 26' E Long). Coll. 1960 and subm. 1969 by M. Escalon de Fonton, Marseille.

\section{Ly-493. Montelus $n^{\circ} 1$, Layer $2 b$}

Carbonaceous earth, Late Cardial, beginning of Sub-Boreal. Comment: as expected, proves upper levels of site were disturbed.

\section{Ly-494. Montclus $n^{\circ}$ 5, Layer 8}

$6230 \pm 150$

4280 в.c.

Charcoal, Late Castelnovian (Late Mesolithic), end of Boreal.

\section{Ly-495. Montclus no 16a, Layer 14}

$\geqslant 6440 \pm 230$

Carbonaceous earth, Late Castelnovian, end of Boreal. Minimal age because only one valid count was made. Coll. 1969.

\section{Ly-496. Montclus $n^{\circ} 16 \mathrm{~b}$, Layer 14}

Carbonaceous earth, Late Castelnovian. Coll. 1964.

\section{Ly-542. Montclus no 19, Layer 16} 5070 B.C.

Bones, Castelnovian, end of Boreal.

General Comment (M. E. de F.): all dates (except Ly-493) agree with stratigraphy and assoc. industries. Confirm previous dates: Ly-303/304: $6220 \pm 100$ for Layer 4; Ly-305/306: $7780 \pm 140$ and Ly-307/308: $7760 \pm$ 260 for lowest Layers $21 \mathrm{~F}$ and 22, Sauveterrian (R., 1971, v. 13, p. 62). Montclus series may be compared to Châteauneuf-lès-Martigues series (this list) where Neolithic industries appeared early (Châteauneuf Layer 8 industry is similar to Montclus Layer 14 industry) (Escalon de Fonton, 1967).

\section{Châteauneuf-lès-Martigues series, Bouches-du-Rhône}

Charcoal from rock shelter Châteauneuf-lès-Martigues, Bouches-du-

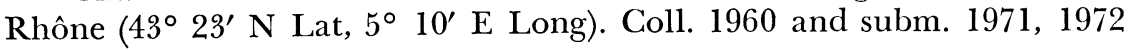
by M. Escalon de Fonton. 


\section{Ly-622. Châteauneuf-lès-Martigues, Foyer 1}

Late Cardial (Neolithic) industry, Atlantic period. Other date on same sample: $\mathrm{Kn}-208: 6700 \pm 200$.

\section{Ly-623. Châteauneuf-lès-Martigues, Foyer 5}

$6070 \pm 490$ Small piece of charcoal; early Cardial in
Other date on same sample: Kn-182: $7520 \pm 240$.

\section{Ly-446. Châteauneuf-lès-Martigues, Cailloutis 6 \\ Cardial industry, Atlantic period.}

Ly-447. Châteauneuf-lès-Martigues, Cailloutis 7 Late Castelnovian (Late Mesolithic), Boreal period.

\section{Ly-624. Châteauneuf-lès-Martigues, Foyer 7}

Late Castelnovian; end of Boreal period.

$$
\begin{aligned}
& 6430 \pm 140 \\
& 4480 \text { в.C. }
\end{aligned}
$$

$$
6420 \pm 120
$$

4470 B.C.

$6780 \pm 240$ 4830 B.C.

\section{Ly-448. Châteauneuf-lès-Martigues, Cailloutis 8b} $7270 \pm 220$

Castelnovian, Boreal period.

\section{Ly-438. Châteauneuf-lès-Martigues, Cailloutis 8 \\ Castelnovian, Boreal period.}

General Comment (M. E. de F.): all dates agree with stratigraphy and assoc. industries, but are younger than age range deduced from the 2 Köln dates. Ly-447 seems a little too young in regard to Ly-446 and -624 and Boreal period, which may be due to eventual stake holes of Neolithic time that pushed down some charcoal from upper layers. Series may be compared to Montclus series (this list and R., 1971, v. 13, p. 62), where Neolithic industries appeared later.

\section{Abri Cornille series, Istres, Bouches-du-Rhône}

Samples from several levels in rock shelter Abri Cornille, near Istres,

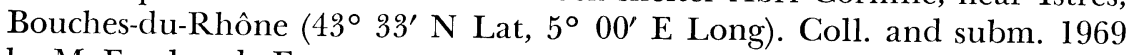
by M. Escalon de Fonton.

\section{Ly-413. Abri Cornille $n^{\circ}$ 1, Layer 6}

$8100 \pm 130$

Humic fraction of charcoal, assoc. with Montadian industry (Early Mesolithic) Dryas III pollen.

\section{Ly-414. Abri Cornille $n^{\circ}$ 3, Layer 9a}

$10,270 \pm 470$

Carbonaceous earth, assoc. with Romanelian (Late Magdalenian) industry, end of Alleröd period. 
Ly-427. Abri Cornille $n^{\circ}$ 5, Layer 10a

$10,870 \pm 320$

Carbonaceous earth, Romanelian, Middle Alleröd. 8920 B.c.

Ly-510. Abri Cornille no 7, Layer 10c

$10,540 \pm 310$ 8590 B.c.

Carbonaceous earth, Romanelian, Middle Alleröd.

Ly-449. Abri Cornille no 9, Layer 12

$10,920 \pm 210$

8970 в.c.

Carbonaceous earth, Early Romanelian, beginning Alleröd.

General Comment (M. E. de F.): Ly-413, obviously too young for Dryas III, is polluted by recent humus. Ly-510 should also be too young but remains in statistical range. Other results agree perfectly with expected ages of industry and generally accepted dates for Alleröd. However, they are a little younger than dates from levels with same industry at La Baume de Vallorgue, Gard, Layer 9-10: Hv-1344/1345: 11,170 200 and Layer 15: Kn-68: 11,300 \pm 115 (Escalon de Fonton, 1966).

\section{Adaouste series, Jouques, Bouches-du-Rhône}

Bones from l'Adaouste grotto, near Jouques, Bouches-du-Rhône $\left(43^{\circ}\right.$ $41^{\prime} \mathrm{N}$ Lat, 5 $5^{\circ} 37^{\prime} \mathrm{E}$ Long). Coll. 1951 and subm. 1971 by M. Escalon de Fonton.

Ly-541. L'Adaouste $n^{\circ}$ 2, Layer 12

$12,280 \pm 190$

Assoc. with Magdalenian V-VI industry of Provence, cold climatic zone attributed to Dryas IIb phase.

\section{Ly-540. L'Adaouste $\mathbf{n}^{\circ}$ 1, Layer 17}

$12,760 \pm 250$

Assoc. with Magdalenian IV of Provence, temperate climatic zone attributed to Boëlling phase.

General Comment (M. E. de F.): both dates agree perfectly with industries and confirm climatic attributions (Escalon de Fonton, 1966). Ly-541 may be compared to Chinchon site, Vaucluse, Layer 15: Ly-597: 12,000 \pm 420 (this list) and to Les Deux-Avens, Ardèche: Ly-321/322: 12,340 \pm 200 (R., 1971, v. 13, p. 63) where Magdalenian has a $\mathrm{N}$ character.

\section{Chinchon series, Saumanes, Vaucluse}

Samples from Chinchon rock shelter, near Saumanes, Vaucluse $\left(43^{\circ}\right.$ 56' N Lat, 5 06' E Long). Coll. 1963 by M. Paccard and subm. 1972 by J. Brochier.

\section{Ly-598. Chinchon, Layer b}

$8980 \pm 850$ 7030 B.c.

Humic fraction of charcoal assoc. with Azilian industry. Comment (J. and J. B.): much too young because level corresponds to a cold climatic phase. This sample is probably polluted by recent humus. 


\section{Ly-597. Chinchon, Layer 15}

$12,000 \pm 420$

Bones assoc. 10,050 B.c. (Escalon (Paccard, 1964). Comment (J. and J. B.): corresponds to Dryas II phase. Seems too young because of several cold climatic oscillations in overlying layers. Expected age was end of Würm III or beginning of Würm IV period (ca. 15,000 в.P.)

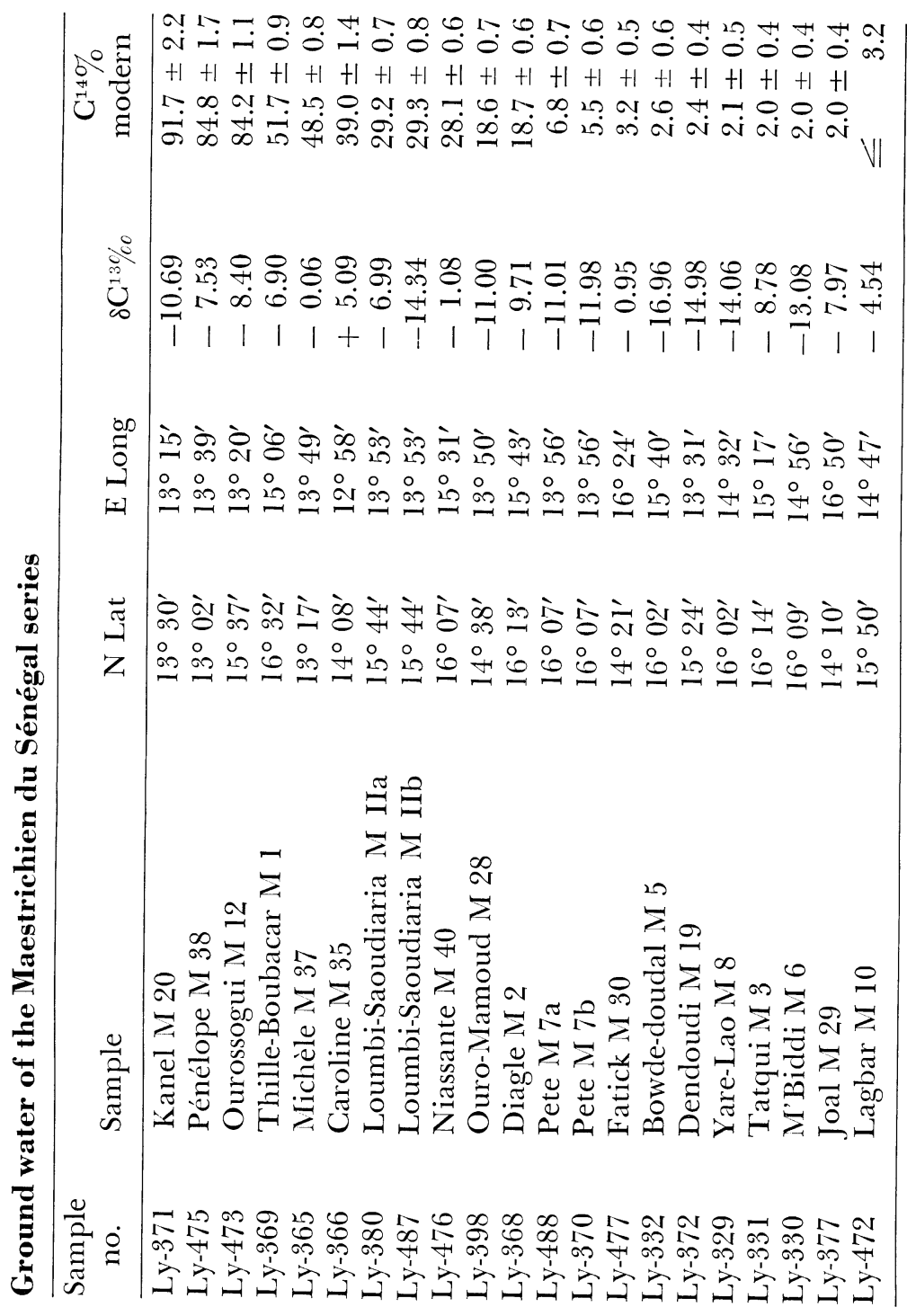




\section{HYDROGEOLOGIC SAMPLES}

The following water samples were subm. for a general study of the two most important aquifer systems of Sénégal, made for the Atomic Energy International Agency (AEIA) in 1970-1971. Samples coll. by M. Diattara and analysis of results were made by $\mathrm{H}$. Moussu and Y. Vuillaume, Bur. Recherches Géol. et Min. Orléans La Source, Loiret. Carbonate species were extracted at sampling sites by $\mathrm{BaCO}_{3}$ precipitation, adding $\mathrm{NaOH}$ and $\mathrm{BaCl}_{2}$ in a $100 \mathrm{~L}$ metal tank, sent to the radiocarbon lab. as a 2L flask filled with $\mathrm{BaCO}_{3}$ mixed with $\mathrm{NaOH}$ solution. Radiocarbon

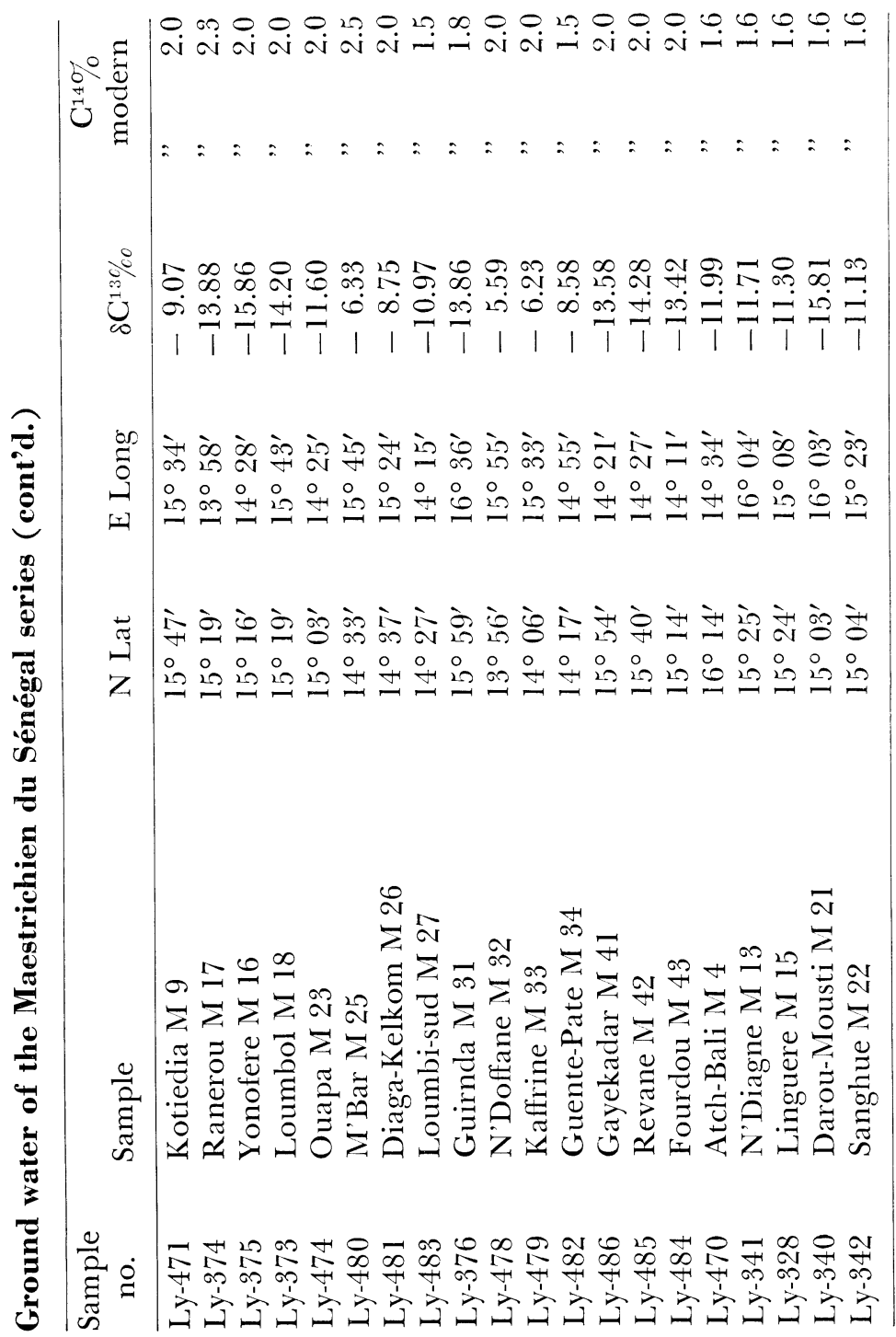


content is reported as \% of modern without $\delta \mathrm{C}^{13}$ correction. Up to Ly-382, $\delta \mathrm{C}^{13}$ was measured by R. Letolle, Lab. Géol. Dynamique, Univ. Paris VI, with a $\pm 0.15 \%$ precision, and from Ly-394, at the radiocarbon lab. with a $\pm 0.05 \%$ precision.

General Comment (Y.V.): $\mathrm{C}^{14}$ contents confirm existence of recent recharge in SE part of aquifer and show another feeding zone, previously unknown, in the Senegal R. sweep, especially in the NW region. Leakage exchanges exist upward, to the overlying ground water (Continental terminal of Senegal). Average flow velocities are ca. 10 to $30 \mathrm{~m}$ per yr horizontally and 1 to $2 \mathrm{~cm} / \mathrm{yr}$ upright (Moussu and Vuillaume, 1972).

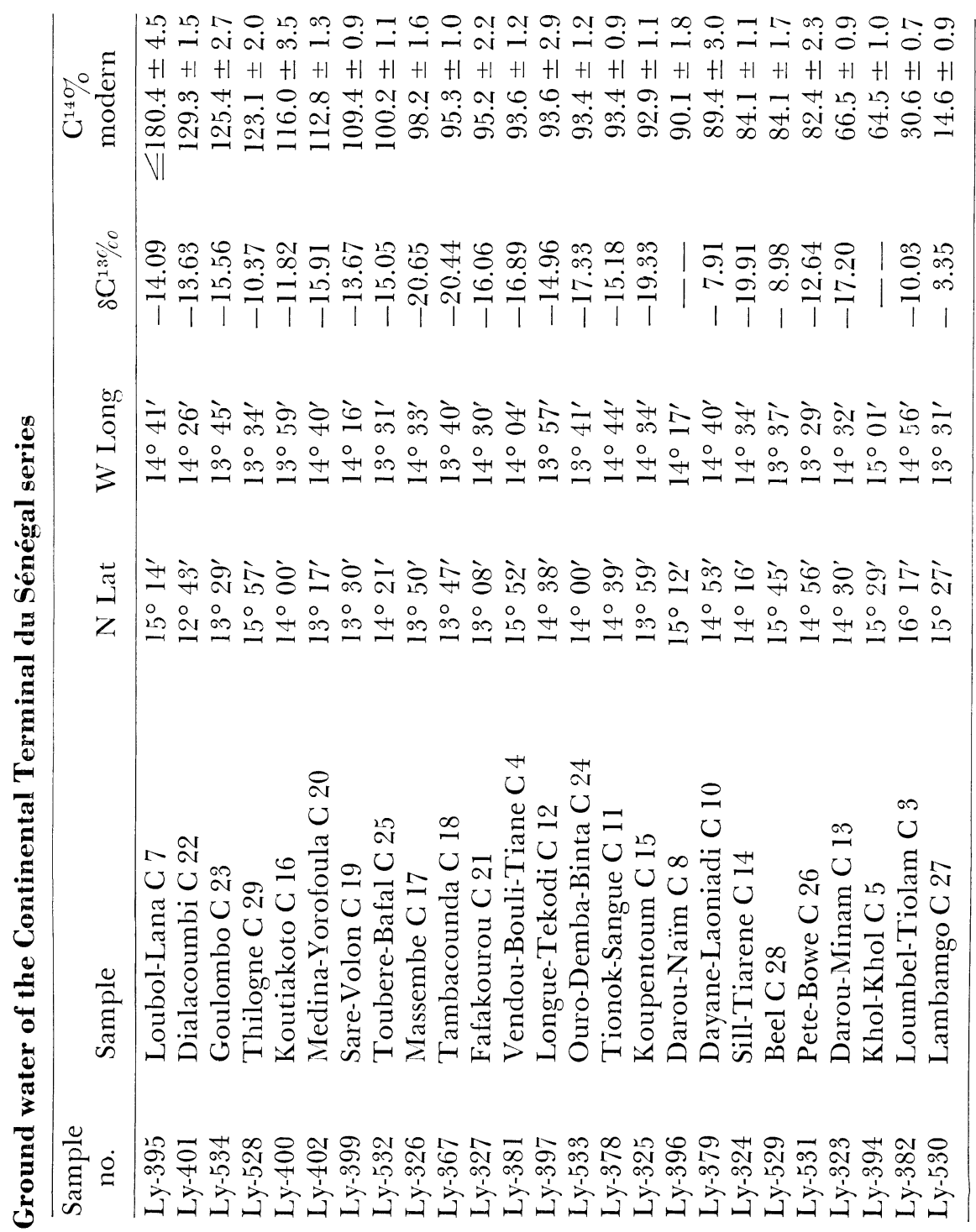


General Comment (Y.V.): in this aquifer, more heterogeneous than ground water of Senegal Maestrichian, radiocarbon values show a feeding zone in central part of basin (Ferlo basin). However, water supply from underlying ground water has not been verified (Moussu and Vuillaume, 1972).

\section{Corrections}

Ly-135, R., 1971, v. 13, p. 59, should read: Ly-133.
Ly-303, " ", " $\quad$ p. $61, \quad, \quad$ " $\quad$ Ly-302.
Ly-12, " $\quad$ p. $64, \quad " \quad$ Ly-312.

REFERENCES

de Beaulieu, J. L. and Evin, J., 1972, Analyses polliniques et datages $\mathrm{C}^{14}$ dans les monts de Lacaune (Tarn): Acad. sci. Lyon IV, Comptes rendus, v. 274, p. 3531-3534.

Chapotat, G., 1972, La voie romaine de Vienne à Lyon par la rive gauche du Rhône: Evocations, in press.

Chapotat, G. and Samuel, E., 1972, Bois et tessons antiques à Eyzin-Pinet, Isère: Soc. linnéenne de Lyon Bull., in press.

Chauviré, C. and Weiss, J., 1962, Découverte d'une nouvelle faune de mammifères dans une haute terrase de la basse vallée de l'Isc̀re: Comptes rendus sommaires de la Soc. Géol. Française, v. 1962, $\mathrm{n}^{\circ}$ 1, p. 18-19.

Combier, J., 1954, La mandibule prétendue magdaléenne d'Arlay: Soc. anthropol. Bull., v. 5, p. $25-26$

1955, Solutré: Les fouilles de 1907 à 1923. Mise au point stratigraphique et typologique: Trav. Lab. Géol. Lyon nouv. sér., ${ }^{\circ}{ }^{\circ}$ 2, p. 99-224.

Crémilleux, André, 1971, Premiers jalons mésolithiques dans le Velay: Assoc. Paléont. et Préhist. Mus. de Lyon Bull., v. 1971, p. 35-37.

Daugas, J. P., 1972, Une fosse à inhumation néolithique à Corent (Puy de Dôme): Actes du 19 congrès de Préhistoire, Le Puy, 1969, Soc. Française Préhist., in press.

Delibrias, G., Guillier, M. T., and Labeyrie, J., 1972, Gif natural radiocarbon measurements VII: Radiocarbon, v. 14, p. 280-320.

Delporte, Henri, 1962, Informations archéologiques de la circonscription auvergne et Limousin: Gallia Préhist., v. 11, $\mathrm{n}^{\circ}$ 2, p. 421-454.

1970, Chronique de la circonscription Auvergne-Limousin: Gallia Prćhist., v. $12, \mathrm{n}^{\circ} 2$, p. $469-470$.

Desbrosse, René, 1971, Les fouilles préhistoriques en Bugey, en 1970-1971: Annales Bugey, v. 58, p. 3-16.

Escalon de Fonton, Max, 1966, Du Paléolithique supérieur au Mésolithique dans le midi méditerranéen: Soc. Préhist. Française Bull., v. 63, n 1, p. 66-180. 1967, Origine et développement de civilisations Néolithiques méditerranéennes en Europe occidentale: Paléohistoria, v. 12, p. 204-248.

1970, Le Paléolithique supérieur de la France Méridionale: Congrès "L'Homme de Cro-Magnon", Alger, 1968, p. 177-195.

Evin, J., Longin, R., Marien, G., and Pachiaudi, C., 1971, Lyon natural radiocarbon measurements II: Radiocarbon, v. 13, p. 52-73.

Evin, J., Longin, R., and Pachiaudi, C., 1969, Lyon natural radiocarbon measurements I: Radiocarbon, v. 11, p. 112-117.

Evin, J., Marien, G., and Pachiaudi, C., 1973, Lyon natural radiocarbon measurements III: Radiocarbon, v. 15, p. 134-155.

Gilot, E., 1970, Louvain natural radiocarbon measurements IX: Radiocarbon, v. 12, p. 553-558.

Gilot, E. and Capron, P. C., 1971, Louvain natural radiocarbon measurements XI: Radiocarbon, v. 13, p. 358-362.

Leclaire, Lucien, 1972, La sédimentation holocène sur le versant méridional du bassin Algéro-Baléares: Mus. Natl. d'Hist. Nat. Mém., sér. C., v. 24, 391 p.

Longin, Robert, 1971, New method of collagen extraction for radiocarbon dating: Nature, v. 230, p. 241-242. 
Moussu, H., and Vuillaume, Y., 1972, Etude par la méthode isotopique de la nappe des sables Maestrichiens et du Continental terminal du Sénégal: Unpub. rept. AIEABRGM n ${ }^{\circ} 72$ SGN 029 AME, $35 \mathrm{p}$.

Paccard, M., 1964, L'Abri ${ }^{\circ} 1$ de Chinchon (Saumanes, Vaucluse): Cahiers ligures de Préhistoire et Archéol., v. 13, p. 3-67.

Pétrequin, P., Piningre, J. F., and Vuaillat D., 1972, Deux fours de potiers hallstattiens à Florange (Moselle): Gallia Préhist., in press.

Riquet, D., 1955, Les sépultures “Aurignaciennes" de Solutré: Trav. Lab. Geol. Lyon, nouv. sér., $\mathrm{n}^{\circ} 2$, p. 2-92.

Roudil, J. L., Coste, A., and Guthez, X., 1970, La Grotte sépulcrale de Boucoiron, Gard: Soc. Française Préhist. Bull., v. 67, n 8, p. 251-253.

Thommeret, J. and Rapaire, J. L., 1964, Monaco radiocarbon measurements I: Radiocarbon, v. 6, p. 194-196.

Vogel J. C. and Waterbolk, H. T., 1963, Groningen radiocarbon dates IV: Radiocarbon, v. 5, p. 163-202.

1967, Groningen radiocarbon dates VII: Radiocarbon, v. 9, p. 107-155. 